\title{
NÁVRH UČEBNICE ENVIRONMENTÁLNEJ GEOGRAFIE
}

\author{
Michaela Strišková, Daša Oremusová
}

\begin{abstract}
Nowadays, we do not have sufficient amount of textbooks in various areas of Education. One of these areas is also Environmental geography which forms a part of primary school Geography lessons. Our intention in this work is mainly to introduce design of textbook for Environmental geography. The textbook introduces and solves environmental issues on global, regional and local level in a very detailed way. The aim of the textbook is to applicate environmental geography in its spatial dimensions into geographical classes mainly at the second grade of primary schools in Slovakia. We created didactic material which helps teachers but also material interesting for students. Our design of the textbook could be very motivational because of amount of picture attachments, additional tasks and games. The content of the textbook deals with environmental issues which are included in ISCED 2 of every primary school in Slovakia.
\end{abstract}

Keywords: environmental geography, playful textbook, ISCED 2

\section{Úvod}

V súčasnej dobe, kedy sa stretávame s čoraz výraznejšími negatívnymi prejavmi l'udskej činnosti, je osveta a vzdelávanie v oblasti environmentálnej geografie takmer nevyhnutná. Problémy životného prostredia sú stále diskutovanou a aktuálnou témou nie len medzi odborníkmi, ale aj bežnými l'ud'mi. Je preto dôležité, aby povedomie o globálnych, ale aj regionálnych či lokálnych problémoch životného prostredia vzrastalo už od prvých rokov života človeka. Environmentálna geografia ako prienik environmentalistiky a geografie študuje životné prostredie a zároveň vplyv človeka na životné prostredie (Huba, 2009). V rámci predmetu geografia na druhom stupni základných škôl sú v Štátnom vzdelávacom programe (ŠVP) zakomponované viaceré environmentálne témy. V súčasnosti sa však väčší dôraz kladie na environmentálnu výchovu, ktorá rieši postavenie človeka $\mathrm{v}$ prostredí a osvetu $\mathrm{v}$ starostlivosti o životné prostredie (Fryková, 2012). Od environmentálnej geografie sa odlišuje prvkom výchovy, ktorý v sebe zahŕňa. V rámci ŠVP sa vyčleňuje prierezová téma Environmentálnej výchovy už na predprimárnom stupni vzdelávania $v$ materských školách. Environmentálna výchova je označovaná ako prierezová téma, čo znamená, že je integrovaná $\mathrm{v}$ rámci iných predmetov. Jednotlivé školy však majú možnost' vyčlenit' ju ako samostatný predmet $\mathrm{v}$ rámci ich volitel'ných hodín. V roku 2013 sa na 242 základných školách na Slovensku realizoval prieskum, ktorý sa zaoberal 
postavením a uskutočňovaním environmentálnej výchovy ako prierezovej témy $\mathrm{v}$ praxi na základných školách. Podl'a učitel’ov, ktorí sa prieskumu zúčastnili, je problémom vyučovania environmentálnej výchovy na Slovensku slabšia materiálno-technická vybavenost' škôl a chýbajúce učebnice (Novanská, 2014). Deficit učebníc, ktoré by sa zaoberali environmentálnymi problémami, sa snažia čiastočne riešit' samotní učitelia, ktorí poskytujú vytvorené učebné materiály prostredníctvom internetových stránok. Medzi prínosné webové stránky v tejto oblasti patria napríklad www.oskole.sk či www.zborovna.sk. Našim návrhom učebnice Environmentálnej geografie, chceme prispiet' k zlepšeniu stavu didaktického materiálu využitel'ného pre vyučovanie environmentálnych tém v geografii.

\section{Teoreticko-metodické východiská}

Učebnica sa zarad'uje medzi základné didaktické pomôcky vo vyučovaní a predstavuje celistvý didaktický text, ktorý prezentuje učivo a napomáha učitel’om pri príprave vyučovacích hodín a žiakom pri osvojovaní si učiva (Turek, 2014).

Problematikou tvorby, popisu a funkciami učebnice ako didaktickej pomôcky sa zaoberalo viacero autorov. Za zakladatel'a teórie učebnice pokladáme Jána Amosa Komenského, ktorý vytvoril prvú ilustrovanú učebnicu Orbis Pictus (Svet v obrazoch). Sformuloval tiež teoretické zásady tvorby učebníc, ktoré ani dnes nestrácajú svoj význam. Podl'a Komenského (In Turek, 2008) má byt’ obsah učebnice úplný, dôkladne premyslený, spracovaný jasne, presne a prehl'adne. Vymedzovaním pojmu učebnice sa vo svojich prácach zaoberajú viacerí autori. Porovnávanie staršieho a novšieho poňatia pojmu učebnica prináša napr. Sikorová (2010), Mikk (2000), Johnsen (1993) či Janko (2012). Průcha (2002) prestavuje tri základné poňatia učebnice. Prvým poňatím je učebnica ako kurikulárny projekt, učebnica ako zdroj obsahu vzdelávania pre žiakov a napokon ako didaktický prostriedok pre učitel'a. Školská učebnica má špecifické vlastnosti, medzi ktoré patrí vybavenost' učebnice aparátom pre riadenie vyučovania a primeranost' učebnice schopnostiam žiakov (Průcha, 1998). V každej učebnici nájdeme typické komponenty, ktoré tvoria jej štruktúru. Model základnej štruktúry učebnice tvorí jej textová a mimotextová zložka. V rámci textovej zložky rozlišujeme text základný, doplňujúci a vysvetl'ujúci. Medzi mimotextové zložky patria aparát organizácie osvojenia, ilustračný materiál a orientačný aparát (Turek, 2008).

Podl'a Zujeva (1986) má učebnica splńat' určité funkcie. Informačnou funkciou učebnice je určit' základné učivo, ktoré si žiak má osvojit'. Transformačnou funkciou je prepracovat' vedecké poznatky do učiva. Ďalšou nevyhnutnou funkciou učebnice je systematickost', ktorá zabezpečuje logické usporiadanie učiva. Okrem spomínaných funkcií má mnoho d'alších, medzi ktoré patrí aj sebavzdelávacia, koordinujúca či výchovná. Turek (2014) ešte vyčleňuje motivačnú funkciu, ktorá je dôležitá najmä $v$ dnešnej modernej spoločnosti 
preferujúcej rôzne technické výdobytky. Pri tvorbe učebnice je tiež potrebné dodržat' podmienku zrozumitel'nosti učebnice. Rozlišujeme štyri dimenzie zrozumitel'nosti, medzi ktoré patria jednoduchost', členenie, stručnost' (výstižnost') a dodatočná stimulácia (Turek, 2014). Podl'a Čižmárovej (2008) by mala učebnica obsahovat' nie len informácie, ale aj všetky etapy vyučovacieho procesu, medzi ktoré zarad’ujeme motiváciu, vymedzenie ciel’ov, aktualizáciu už osvojeného učiva, ale aj osvojenie, upevnenie a prehíbenie nového učiva.

Otázkou ako tvorit' učebnicu sa vo svojom diele zaoberal aj Mladý (1988), ktorý vyčlenil fázy tvorby učebnice. Prvou fázou tvorby je vypracovanie osnovy učebnice. Osnova má nadväzovat' na osnovy predmetu a nemôže sa od nich odkláňat', jej rozsah sa ale môže líšit' od rozsahu predmetových osnov. Ďalším krokom je príprava materiálu pred samotnou tvorbou učebnice. Dôležitým krokom je tiež vytvorenie harmonogramu tvorby učebnice, kde zohl'adníme náročnost' jednotlivých tém. Tvorba učebnice pokračuje prípravou a tvorbou rukopisu a na záver technickou prípravou a tlačou. Podl'a Lepila (2010) je pre prírodovedné predmety dôležité tiež využívanie rôznych zbierok úloh či pracovných listov, ktoré môžu priamo nadväzovat' na danú učebnicu.

Učebnicová politika na Slovensku je zložitá, čo v konečnom dôsledku odrádza potencionálnych autorov učebníc. Tvorba učebníc, ich výber a schval'ovanie sa na Slovensku riadi podl'a smernice č.10/2011, ktorá upravuje postup MŠVVaŠ.

V oblasti environmentálnej výchovy evidujeme na Slovensku pät’ učebníc pre 2. stupeň ZŠ pre 5. až 9. ročník pod názvom Environmentálna výchova spracované Blahovou a kol. (2014). V geografii však nebola doposial' publikovaná žiadna učebnica environmentálnej geografie určená pre základné školy.

\section{Environmentálne témy v rámci Štátneho vzdelávacieho programu pre druhý stupeň základných škôl}

Geografia sa zarad'uje do vzdelávacej oblasti človek a spoločnost'. Obsah predmetu geografia sa okrem iného sústredí aj na väzby medzi človekom a prírodou. Žiaci sa na hodinách geografie učia ako reagovat', porozumiet' a riešit' problémy, ktoré pramenia $\mathrm{z}$ aktivít človeka a ich dopadu na prírodu a societu (ŠVP, 2010). Vybrané environmentálne témy sa vyučujú priamo na hodinách geografie. Školy však disponujú volitel'nými hodinami, kde môžu venovat' environmentálnym problémom vyššiu pozornost'. Obsah geografie v ŠVP z roku 2010 sa environmentálnym problémom venuje vo vyššej miere, v porovnaní s Inovovaným ŠVP (2014), kde témy spojené s problémami životného prostredia sú mierne zredukované. Environmentálne témy boli do vyučovacieho predmetu geografia implementované $\mathrm{v}$ rámci tém o narušení a ochrane prírodných zložiek životného prostredia ale aj globálnych problémoch l'udstva (Madziková, 2001). Pre žiakov je dôležité študovat' environmentálne problémy tiež v miestnom regióne, pretože 
práve to je východiskom, aby žiaci porozumeli globálnym problémom životného prostredia. V tab. 1 sú uvedené niektoré z environmentálnych tém zahrnutých v ŠVP z roku 2010.

Tab. 1: Environmentálne témy v geografii (ISCED 2)

Table 1: Environmental topics in Geography (ISCED 2)

\begin{tabular}{|c|l|}
\hline \multicolumn{1}{|c|}{ Región } & \multicolumn{1}{c|}{ Environmentálne problémy } \\
\hline \multirow{2}{*}{ Afrika (6. ročník) } & $\begin{array}{l}\text { Problémy v Afrike (hlad, choroby,...) } \\
\text { Rozširovanie púští (sahel) } \\
\text { Nedostatok potravín }\end{array}$ \\
\hline \multirow{3}{*}{ Ázia (6. ročník) } & $\begin{array}{l}\text { Nadmerná hustota zal'udnenia určitých } \\
\text { oblastí v Ázii }\end{array}$ \\
& $\begin{array}{l}\text { Hrozby tajfúnov, zemetrasení a } \\
\text { povodní } \\
\text { Živelné pohromy v Ázii - cunami, } \\
\text { zemetrasenia, sopečná činnost', }\end{array}$ \\
\hline \multirow{2}{*}{ Európa - náš svetadiel (7. ročník) } & $\begin{array}{l}\text { Exhaláty, smog, } \\
\text { Vplyv dopravy na životné prostredie } \\
\text { Prírodné a kultúrne zaujímavosti }\end{array}$ \\
\hline Amerika - Nový svet (9. ročník) & Príčiny odlesňovania v Južnej Amerike \\
\hline
\end{tabular}

Zdroj: ŠPÚ, 2010

\section{Návrh učebnice Environmentálnej geografie}

Prezentovaná učebnica environmentálnej geografie je originálnym, nami vytvoreným učebným materiálom pre žiakov 2. stupňa základných škôl. Pozostáva z troch hlavných kapitol, ktoré boli vyčlenené na základe geografických dimenzií, od globálnej, cez regionálnu až po lokálnu úroveň. Učebnicu sme vytvorili za účelom skvalitnenia vyučovania environmentálnych tém na hodinách geografie, ale aj iných vyučovacích predmetov.

Každá kapitola sa d’alej člení na podkapitoly, v ktorých sú environmentálne problémy usporiadané podl'a zložiek životného prostredia od ovzdušia, vody, pôdy, hornín až po rastlinstvo a živočíšstvo.

Návrh učebnice Environmentálnej geografie obsahuje textové aj mimotextové zložky. V rámci textových zložiek učebnice je obsiahnutý základný, doplňujúci, ale aj vysvetl'ujúci text. Obsah učebnice d’aleko presahuje témy zo ŠVP z oblasti geografie. Žiaci v nej nájdu množstvo informácí́ o environmentálnych problémoch, ktoré sú zamerané na príčiny, dôsledky a možné riešenia daných problémov životného prostredia. Na globálnej úrovni sa učebnica zaoberá najvýraznejšími celosvetovými environmentálnymi problémami, z hl'adiska regionálnej úrovne je zameraná na Slovensko a lokálna úroveň sa 
venuje obci Rabča. Ukážku spracovania globálnej úrovne vybraného environmentálneho problému znižovania biodiverzity prezentuje obr. 1, regionálnu úroveň obr. 2 a napokon lokálnu úroveň obr. 3.

Obr. 1: Znižovanie biodiverzity vo svete

Figure 1: Biodiversity loss in the world

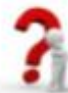

\section{Strata bicdiverzity}

Čo je to biodiverzita?

Diverzita $\Longrightarrow$ rozsah obmien, rôznorodosti alebo odlišnosti medzi súborom určitých vlastnosti

Biodiverzita je mnohotvárnost' alebo rozmanitost' żivota v rámei druhov, medzi druhmi i medzi ekosystémami.

\section{História Termin biodiverzita v jeho dlhom tvare - biologiclei diverzina proý larit pouthil vedec Lovejoy v rolas 1980 a je bežne poużivany na opis počtu drubov. Na definicii tohto terminu sa podielali konferencie o biologickej diverzite z roks 1981 a 1986 vo Washingtone.}

Takmer štvrtina volne žijúcich druhov v Euxópe je v súčasuosti ohrozená vyhynutim.

Hlavué príciny straty biodiverzity:

zmeny krajiny v dôsledku ludskej činnosti, najmă polnohospodárstvo

$\Rightarrow$ rozširovanie miest a dopravnej infraštruktúry

D deforestácia (odlesñovanie)

znečistenie ovzdušia, vody, pody

Dadmené využivanie prirodných zdrojov

(rybolov, banictvo, t'ažba dreva)

blimatická zmena
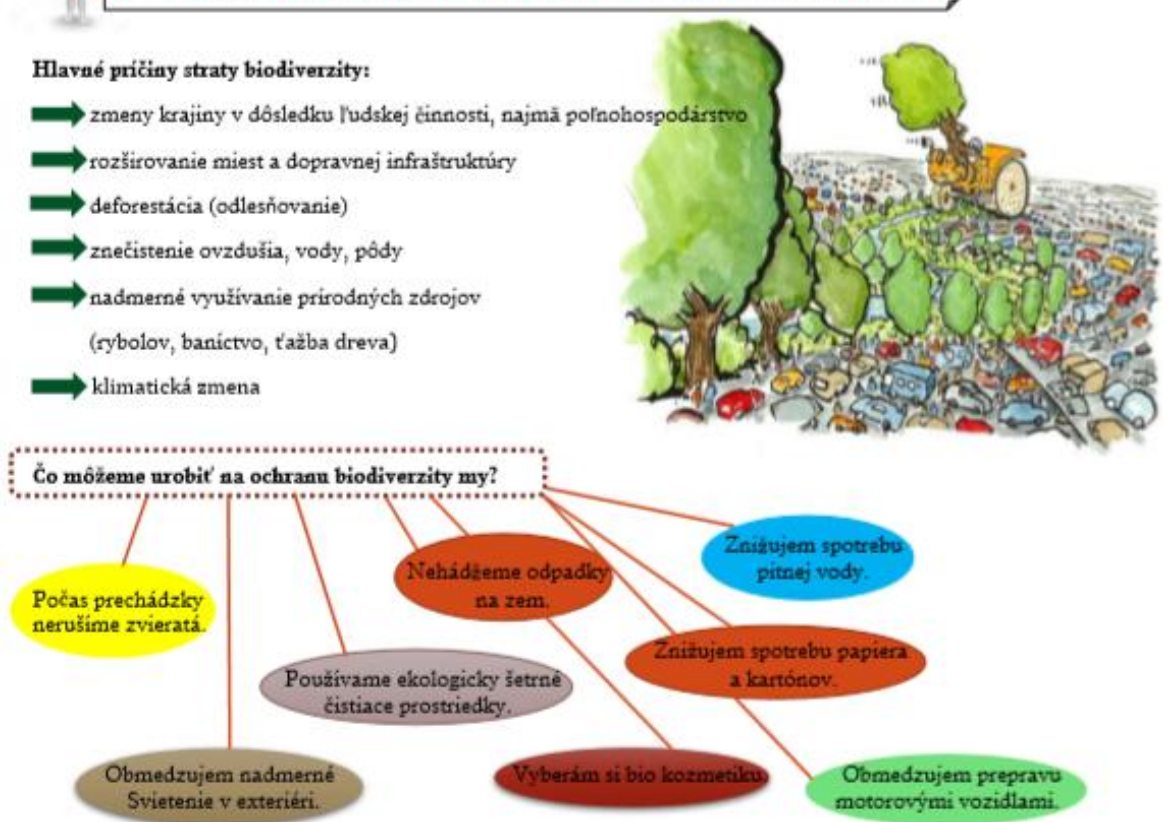


\section{Obr. 2: Znižovanie biodiverzity na Slovensku}

Figure 2: Biodiversity loss in Slovakia

\section{5 Strata bicdiverzity na slovensku}

\section{Dôležité fakty}

$\mathrm{V}$

súčasnosti takmer $1 / 4$ volne žijúcich druhov rastlin a živočichov v Európe hrozi vyhynutie. Situácia nie je priaznivá ani na územi Slovenska. Podla MŽP SR je v súčasnosti ohrozených $11,4 \%$ nižších rastlin vrátane húb a $14,6 \%$ vy̌ššch rastlin. Viac ako $40 \%$ územia Slovenska je pokrytých lesným porastom a takmer polovicu územia Slovenska zaberá pol'nohospodárska pôda. $Z$ hl'adiska ochrany je

$1 / 4$ územia chránenou oblast'ou. $Z$ lesných porastov je až $60 \%$ ohrozených či zničených.

\section{Pričiny znižovania biodiverzity}

znečist'ovanie ovzdušia, vody a pôdy,

$\Rightarrow$ zmena klimy,

$\Rightarrow$ rozširovanie inváznych druhov,

$\Rightarrow$ budovanie ciest, urbanizácia.

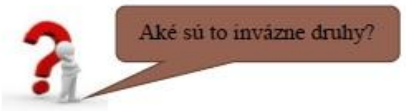

Slovo invázia má pôvod $\mathrm{v}$ latinčine a znamená vtrhnuit', vniknit' alebo vpadmut'.

V súvislosti s inváznymi druhmi rastlin a živočichov hovorime o druhoch, ktoré sú nepôvodné (napr. agát biely (Robinia pseudoacacia), netýkavka žliazkatá (Impatiens glandulifera). Tieto druhy vymedzuje aj slovenský zákon 543/2002 Z.z. o ochrane prirody a krajiny. Podla neho sa za invázny druh považuje nepôvodný druh, ktorého vniknutie alebo samovol'né širenie ohrozuje biologickú rozmanitost.

Najohrozenejšimi biotopmi nie len na územi Slovenska ale aj Európy sú rašeliniská, mokrade a zaplavované
lúky, pričom až $52,4 \%$ biotopov je v nepriaznivom stave. Práve preto sú zapisané do svetového Zoznamu
mokradi medzinárodného významu - Ramsarského dohovoru. Zoznam obsahuje viac než 1368 lokalit
s celkovou plochou viac ako 119 miliónov hektárov (2004). Ramsarský dohovor je prvým novodobým
medzinárodným dohovorom na ochranu a využivanie mokradi. Dohovor bol podpisaný 2 . februára 1971 v
Ramsare (Irán) a podpisalo ho 168 krajin. Slovenská republika pristúpila k Ramsarskému dohovoru v roku 1990
so svojimi 14 lokalitami. Na regionálnej úrovni sa Ramsarský dohovor presadzuje aj prostredníctvom
Karpatskej iniciativy pre mokrade, kde je združených 7 karpatských krajin.

Chrảnené rastlinstvo a živočišstvo Slovenska

Na územi Slovenska najjdeme množstvo chrảnených, či ohrozených rastlin a živočíchov. Kompletný zoznam ohrozených druhov bol vypracovaný Štátnou ochranou prirody Slovenskej republiky (ŠOP SR) v knihe „Červený zoznam rastlín a živočichov Slovenska" z roku 2001.

Prehlad ohrozenosti rastlin (2014)

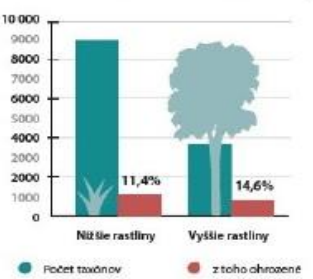

Prehlad ohrozenosti stavovcov (2014)

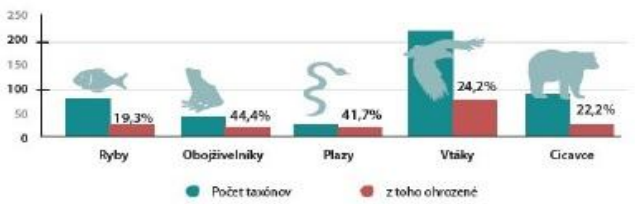

Zarư ŞOPSR

Graf 7 a 8 Prehlad ohrozenosti rastlin a živočišnych stavovcov na územi Slovenska 
Obr. 3: Znižovanie biodiverzity - obec Rabča

Figure 3: Biodiversity loss - village Rabča

\subsection{Droblém biodiverzity a deforestácie v cbci Rabča}

Územie obce Rabča poskytuje vhodné podmienky na zachovanie pestrej biodiverzity. V obci sa vyskytujú rôzne hodnotné ekosystémy a európsky významné spoločenstvá sohrozenými druhmi rastlinstva a živočišstva.

Významné oblasti so vzácnymi a ohrozenými druhmi rastlinstva a živočišstva, ktoré sa v obci nachádzajú sú aj genofondové plochy. Zo vzácnych druhov rastlinstva môžeme spomenút druhy, ktoré sa vyskytujú v zamokrených oblastiach, napríklad ostrica dvojdomá (Carex dioica), všivec močiarny (Pedicularis palustris), tučnica obyčajná (Pinguicula vulgaris), hviezdoš močiarny (Callitriche palustris) a d’alšie. Medzi vzácne druhy živočišstva patria napriklad bocian čierny (Ciconia nigra), orol kriklavý (Aquila pomarina), či obojživelnik mlok karpatský (Triturus montandoni).

Genofondové plochy sú územia, na ktorých sa zámerne pestujú vzácne druhy rastlin alebo chovajú živočichy kvôli zachovaniu ich biodiverzity.

V Rabči sa nachádzajú tri genofondové plochy:

Žabinec - južná čast územia Rabče, v ktorej sa nachádzajú rašelinové lúky a slatiny s výrazným výskytom vachty trojlistej (Menyathes trifoliata),

mokrade Polhoranky - najjužnejšia čast' obce s prechodom do susednej obce Zubrohlava, kde sa vyskytujú vzácne druhy vtáctva, napr. đ’atel’ trojprstý (Picoides tridactylus) a obojživelnikov, napr.

Pod Hájkou - západná čast územia obce s výskytom rašelinných lúk a slatín, na ktorých rastú chránené druhy rastlin, napriklad vstavačovec májový (Dactylorhiza majalis), kruštik močiarny (Epipactis palustris) či vemennik dvojlistý (Platanthera bifolia).

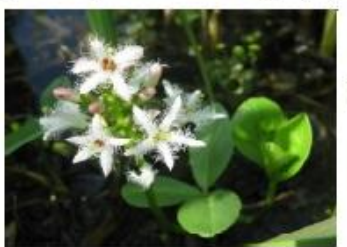

Obr. 39 Vachta trojlistá

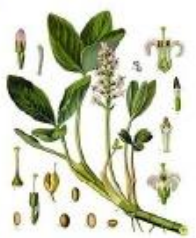

Obr. 10 Vývin lvetov vachty trojlistej

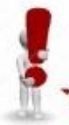

Nojon

Najnižšiu úroveñ biodiverzity sledujeme v oblastiach, ktoré sú intenzivne obhospodarované, najmä polia a lúky s monokultírami (prevláda jeden dnuh rastliny) Tiefo územia sa nachádzajín: $\because$ *... v severnej časti obce a rozširujú sa po stranách zastavaného územia, ale aj v južnej časti obce: " výchudue ud zastavaného územia.

Najviac obhospodarovanými územiami sủ tie, ktoré sa nachádzajú v okoli rieky Polhoranky, tzn. zastavaného územia obce. Vzdialenejšie pozemky sa $\mathrm{v}$ minulosti využivali ako orná pôda, dnes sa využivajú ako lúky a pasienky. Okraje lúk a pasienkov pomaly zarastajú drevinami, čo spôsobuje, že sa meni druhové zloženie. Na pıvý pohl'ad sa zuá, že lento jav je puzilivny, z liladiska ıužsinovania lesnélı živočíšstva. Na dıuhej stıane to pôsobi negativne na biodiverzitu lúk, ktoré neznášajú takúto konkurenciu.

Žiaci v učebnici nájdu okrem základného textu, aj rôzny doplňujúci text či úlohy na upevnenie alebo zopakovanie osvojeného učiva. Úlohy sú prezentované 
prostredníctvom otázok na zopakovanie, alebo úlohami na dopĺn̆anie či hl’adanie d’alších informácií. Našou prioritou pri úlohách bolo tiež využívanie medzipredmetových vzt’ahov, napríklad s biológiou (obr. 4), dejepisom. Pri riešení úloh žiaci využívajú získané vedomosti, ale pracujú aj s atlasmi či internetom. Ciel'om učebnice je zaujímavým a názorným spôsobom obohatit' vyučovanie geografie v problematike environmentálnych problémov, ktoré sa týkajú každého z nás a ukázat' žiakom možnosti riešenia jednotlivých problémov.

Obr. 4: Úloha na dopĺn̆anie

Figure 4: Fill the blank spaces

\section{Úloha:}

Prirađte $\mathrm{k}$ obrázkom živočichov ich názvy:

vidlochvost feniklový, kunka žltobruchá, jastrab lesný, datel trojprstý, užovka obojková.
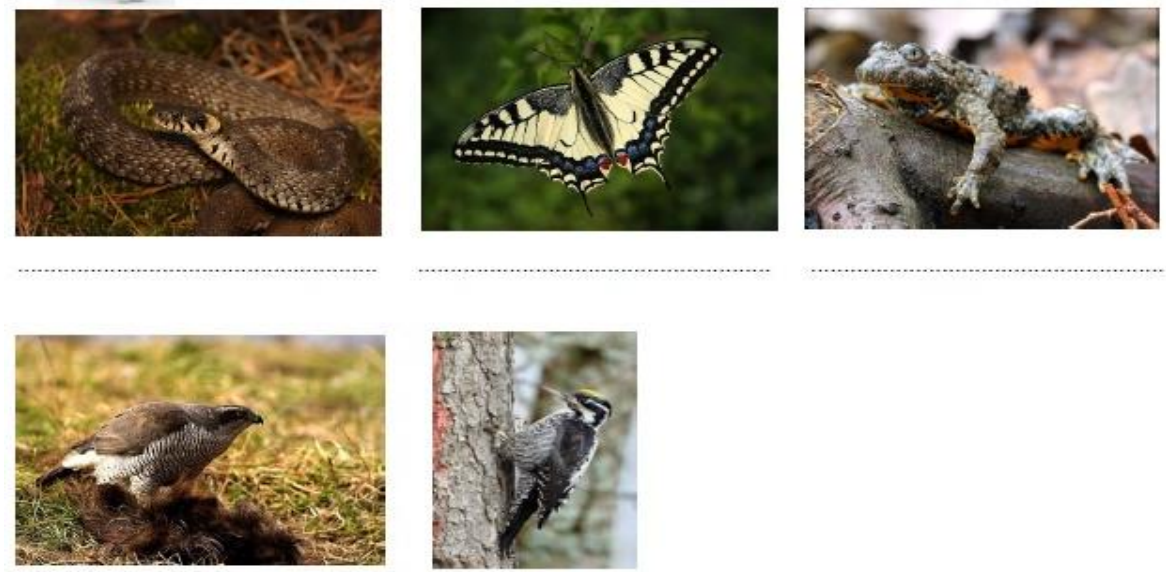

Učebnica je tvorená tak, aby sa dala uplatnit' vo všetkých fázach vyučovania. Obsahuje časti, ktoré majú za úlohu motivovat' žiakov, prezentovat či upevnit' nové učivo. Textová čast' je obohatená o množstvo zaujímavostí zo sveta, Slovenska a obce Rabča (obr. 5). Obsahuje odkazy na internetové stránky, kde si žiaci môžu pozriet' napríklad ako rastie svetová populácia každú sekundu (obr. 6). Odkazuje tiež na aplikácie, ktoré si žiaci môžu stiahnut' do svojich tabletov či smartfónov (obr. 7). Reagujúc na súčasné postoje mladej generácie voči tradičným učebniciam, sme sa pokúsili zostavit' učebnicu, ktorá by mala moderné či modernejšie prevedenie. Preto je učebnica koncipovaná tak, aby nebola len tradičnou didaktickou pomôckou, ale obsahuje aj časti, pri ktorých žiaci využívajú moderné informačno-komunikačné technológie. 
Obr. 5: Vedeli ste, že...?

Figure 5: Do you know that...?

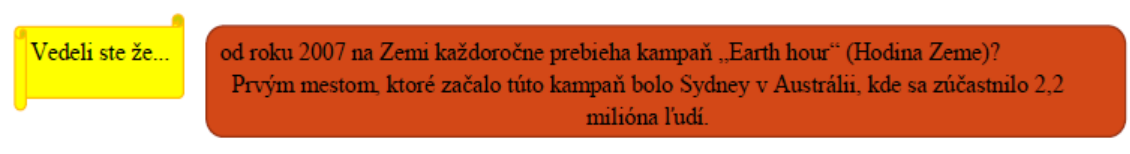

$\mathrm{O}$ čo vlastne ide?

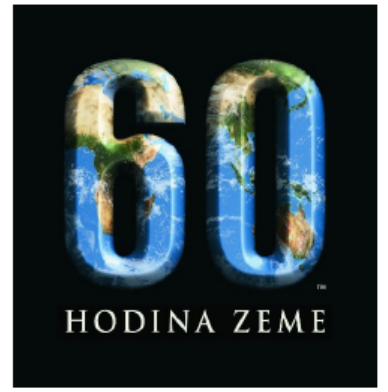

Ide o symbolické vypinanie svetiel $\mathrm{v}$ mestách či domácnostiach po celom svete na jednu hodinu, ktoré sa snaží o zvýšenie povedomia verejnosti v oblasti klimatických zmien. Tento rok (2018) sa bude konat' 24 . marca od 20:30 do 21:30. V roku 2016 sa ku kampani pripojilo 178 krajín sveta, vrátane Slovenska. V roku 2018 sa Slovensko zapojí už po deviaty krát. Zúčastnit' sa môžeš aj ty, ked' na hodinu vypneš svetlá vo svojej domácnosti.

V roku 2017 sa na Slovensku do kampane zapojilo 49 miest a obcí, 40 pamiatok, 69 organizácií a firiem a 30 základných a stredných škôl.

Obr. 6: Svetová populácia Figure 6: World population

Vođa hrá v živote človeka významnú úlohu. Bez vođy by človek neprežil. Medzi základné funkcie vody patria: biologická (výživa), zdravotná, hygienická, dopravná, strategická a v neposlednom rade rekreačná a estetická.

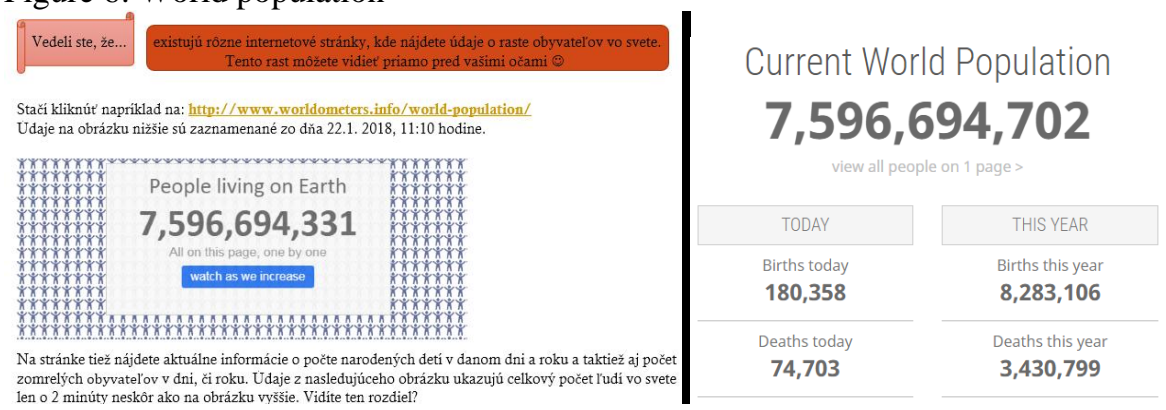


Obr. 7: Atlas odpadov

Figure 7: Waste atlas
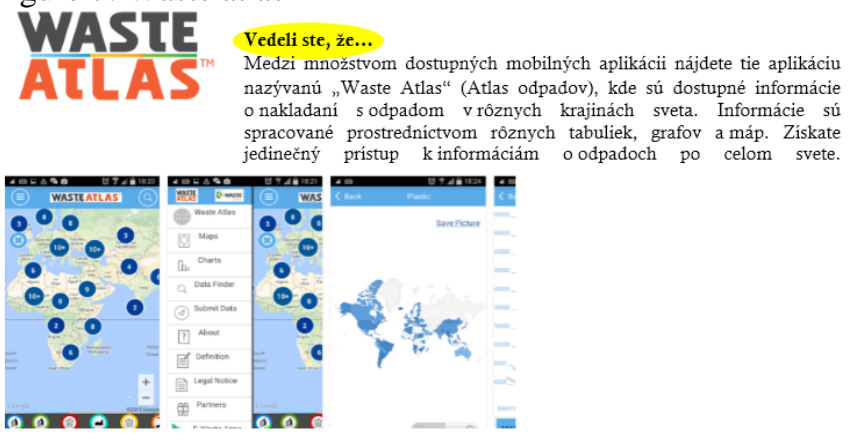

Obr. 11 Aplikácia Waste Atlas

V rámci motivačnej fázy vyučovania sa $\mathrm{v}$ učebnici dajú využit' didaktické hry, ktoré sa žiaci môžu zahrat' pred preberaním nového učiva alebo ako formu upevňovania prebraného učiva. Hry sú určené na prácu v skupinách, čo prispieva k socializácii žiakov a upevňovaniu triednych vzt’ahov (obr. 8 a 9). Didaktické hry je možné hrat' v interiéri školy, ale aj v exteriéri, kde žiaci majú možnost' absolvovat' s učitel'om pobyt vonku a pozorovat' zmeny, ktoré sa v prostredí pôsobením človeka dejú.

Obr. 8: Odborník na ozónovú vrstvu Figure 8: Ozone layer expert
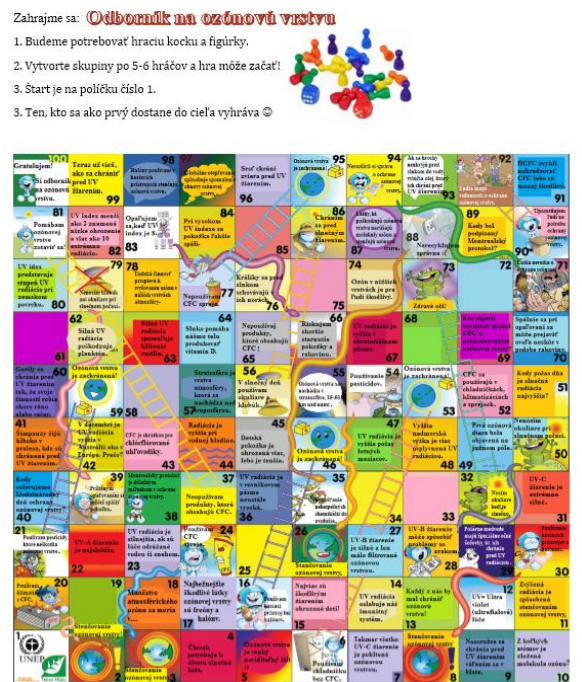

Obr. 9: Bingo

Figure 9: Bingo

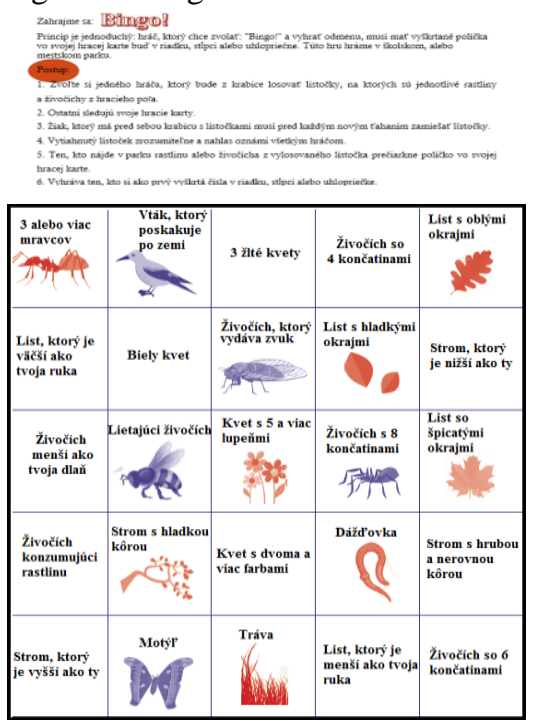


Učebnica je zároveň doplnená aj neštandardnými čast’ami v podobe napr. komiksov, ktoré vtipným a mladým l'udom blízkym spôsobom upozorňujú na environmentálne problémy (obr. 10).

Obr. 10: Komiksy

Figure 10: Comics
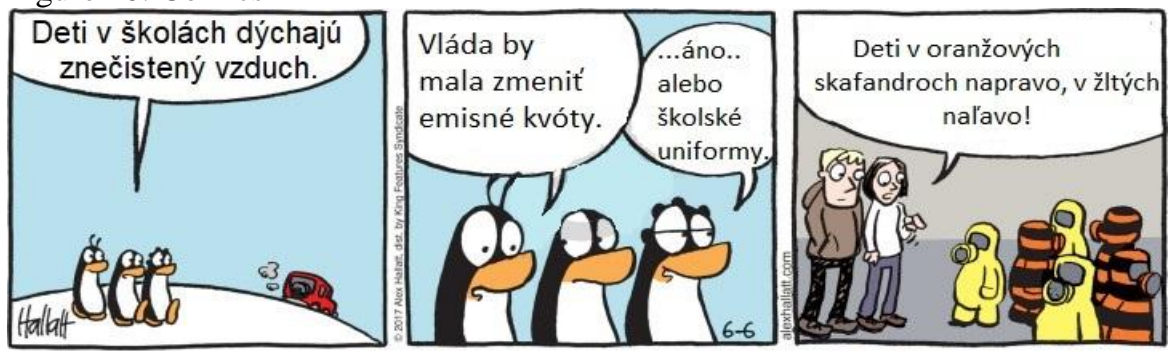

CAvex Hallat

\section{Komiks}
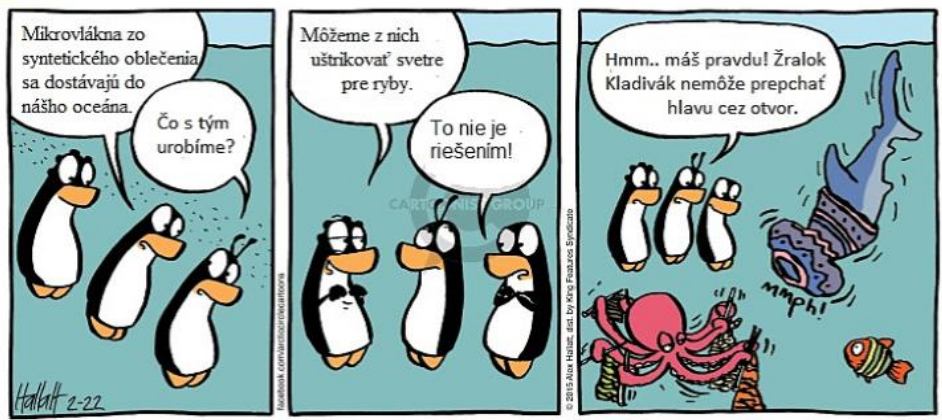

Geografia patrí medzi prírodovedné predmety, pre ktoré je často dôležité, aby žiaci mohli na hodinách experimentovat' a videli problémy reálne. Metóda experimentu (pokusu) má v geografii špecifické postavenie, pretože názornost' pri vyučovaní geografie, patrí medzi jej hlavné záujmy. Pri pokusoch môžeme uplatnit' aj d’alšie vyučovacie metódy ako napr. prácu s grafmi či štatistickými údajmi.

Vel'mi zaujímavé by mohlo byt' spestrenie pokusu využitím heuristickej metódy DITOR, ktorá podl'a svojho názvu obsahuje nasledujúce zložky: (D definuj problém, I - informuj o probléme, $\mathrm{T}$ - tvor riešenia, $\mathrm{O}$ - ohodnot' nápady, $\mathrm{R}$ - realizuj nápady v praxi). Jednotlivé zložky tejto metódy môžeme využit' ako čiastkové úlohy počas pokusu. V ukážke prezentujeme pokus obsiahnutý $\mathrm{v}$ učebnici, ktorý demonštruje skleníkový efekt za pomoci dvoch plastových fliaš, jednej odkrytej a druhej zakrytej (obr. 11). Učebnica ponúka žiakom tiež tabul'ku a grafy na zakreslenie zistených informácií. 
Obr. 11: Experiment na tému skleníkového efektu

Figure 11: Experiment within the topic of Greenhouse effect

\section{Pokus}

Pomôcky: dve plastové fl'aše, 2 teplomery, lepiacu pásku, fóliu, farebné pastelky, troška pôdy a stolnú lampu.

Postup:

1. Vytvoríme skupiny po 4-5 žiakov (:)

2. Odrežeme vrchnú čast' fl'aše a nasypeme do nej pôdu.

3. Prilepíme do vnútra teplomer pričom na jeho spodnú čast' nalepíme

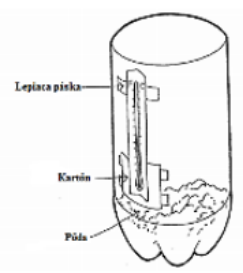
kartón, aby nebola vystavená priamemu teplu.

4. Jednu z fliaš zakryjeme fóliou a druhá ostane odokrytá.

5. Obe fl'aše umiestnime pod lampu a sledujeme, čo sa deje s teplotou na oboch teplomeroch (ak nemáme dostatok stolných lámp, umiestnime fl'aše na slnečné miesto, napr. na okno).

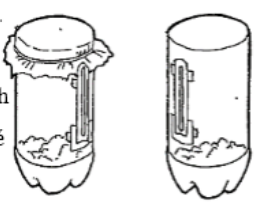

6. Následne po dobu 15 min. sledujeme teplotu a každú minútu ju zaznamenáme do tabulky.

7. Udaje zaznačíme do grafu a výsledné hodnoty prediskutujeme.

Okrem práce s učebnicou na hodinách geografie či iných predmetov, žiaci nájdu v učebnici rôzne pokusy, ktoré si môžu overit' aj v domácom prostredí. Učebnica ponúka žiakom, ale aj rodičom praktické, každodenné rady, ktorými môžu prispiet' k zlepšovaniu stavu životného prostredia nie len na lokálnej úrovni, ale aj regionálnej, dokonca globálnej úrovni. Napríklad pri téme znižovania biodiverzity si žiaci prečítajú, ako prispiet' k zachovaniu stavu biodiverzity (obr. 12). Súčast’ou je taktiež následná diskusia žiakov či návod na vytvorenie vlastnej nádoby na kompostovanie za pomoci rodičov.

Obr. 12: Rady pre zachovanie biodiverzity

Figure 12: Tips for Biodiversity conversation

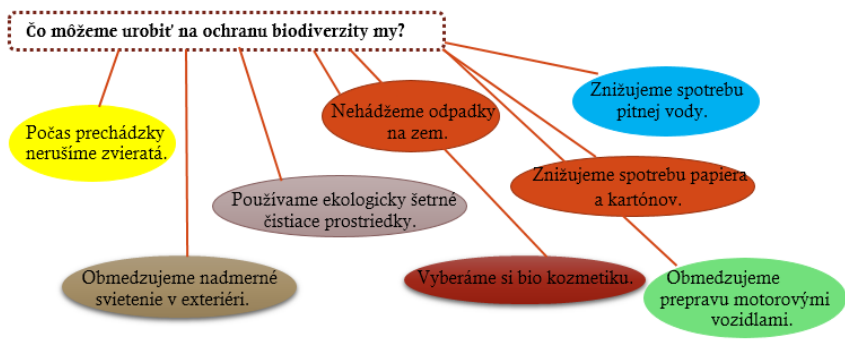

Diskutujeme:

D Akými d'alšími spôsobmi môžeme my sami chránit' prírodu pred stratou biodiverzity?

$\Sigma$ Čo môže nastat', ked' sa l'udia nebuđú snažit' chránit' biodiverzitu? Vysvetlite na daných príkladoch. 
Grafické spracovanie učebnice je koncipované tak, aby jeho farebnost' a zaujímavost' boli pre žiakov motivačné $\mathrm{k}$ ich d’alšiemu štúdiu. Učebnicu sme tvorili pomocou funkcií, ktoré ponúka program Microsoft Word. V rámci jednotlivých tém sa žiaci budú stretávat' s dvoma piktogramami (obr. 13), ktoré upozorňujú na zaujímavost' či dôležitý fakt, alebo sa ich niečo pýtajú a žiadajú o pomoc. Sprevádzajú žiakov celou učebnicou dodávajú jej tak hravý charakter.

Obr. 13: Piktogramy

Figure 13: Pictograms
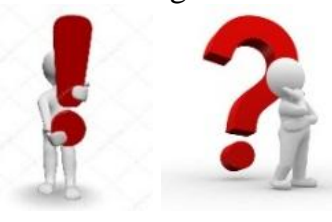

\section{Záver}

Návrh Učebnice environmentálnej geografie má slúžit' najmä pre potreby žiakov druhého stupňa základných škôl, pričom vybrané časti učebnice je možné využívat' tiež na prvom stupni $\mathrm{v}$ rámci vyučovacieho predmetu vlastiveda. Učebnica je vhodná nie len na vyučovanie environmentálnych tém v geografii, ale aj ako doplnková literatúra $\mathrm{v}$ rámci environmentálnej výchovy ako samostatného volitel'ného predmetu. Považujeme za dôležité zdôraznit', že návrh učebnice v sebe zahŕňa ovel'a rozsiahlejšie a detailnejšie riešené pole environmentálnych problémov ako nájdeme $\mathrm{v}$ rámci geografie a tém ŠVP pre druhý stupeň základných škôl.

Našim hlavným ciel'om bolo dosiahnut', aby sa žiaci viac zaujímali o environmentálne problémy súčasného sveta. V troch hlavných kapitolách a niekol'kých podkapitolách sa žiaci dozvedia o príčinách, dôsledkoch a výskyte environmentálnych problémov na globálnej, regionálnej a lokálnej úrovni. Jednotlivé environmentálne témy sú spracované formou, ktorá je zaujímavá a hravá, ale na druhej strane náučná. V rámci štylizácie textu bolo snahou nepret'ažovat' žiakov vel'kým množstvom cudzích slov. Cudzie slová, ktoré by mohli byt' pre žiaka náročné, sme uvádzali so slovenským ekvivalentom, prípadne s jednoduchým vysvetlením. Grafické spracovanie učebnice je koncipované tak, že dôležité informácie sú zvýraznené v rôznych geometrických útvaroch, ktoré poskytuje program Microsoft Word. Celou učebnicou žiakov sprevádzajú dva druhy piktogramov, ktoré žiakov na niečo upozorňujú, alebo sa ich pýtajú a hl'adajú odpovede.

Našou snahou bolo vytvorit' modernú učebnicu, ktorá by svojim charakterom bola atraktívna pre dnešných žiakov. Vzhl'adom na informačnú spoločnost' sa tak v učebnici nachádzajú rôzne úlohy, ktoré žiaci riešia pomocou 
internetu, alebo odkazy na webové stránky či aplikácie. V dnešnej modernej dobe je zvlášst' náročné vzbudit' záujem a motivovat' žiakov vo vyučovacom procese. Veríme, že aj tento návrh Učebnice environmentálnej geografie je jedným z riešení ako zaujat' pozornost' žiakov a motivovat' ich k väčšiemu záujmu o poznanie environmentálnych problémov.

\section{Literatúra}

BLAHOVÁ, S. a kol. 1994. Environmentálna výchova pre 5. ročník. Bratislava: Strom života, 1994. $36 \mathrm{~s}$. ISBN 978-80-88688-75-4.

BLAHOVÁ, S. a kol. 1994. Environmentálna výchova pre 6. ročník. Bratislava: Strom života, 1994. 37 s. ISBN 978-80-88688-76-1

BLAHOVÁ, S. a kol. 1994. Environmentálna výchova pre 7. ročník. Bratislava: Strom života, 1994. 27 s. ISBN 978-80-88688-77-8

BLAHOVÁ, S. a kol. 1994. Environmentálna výchova pre 9. ročník. Bratislava: Strom života, 1994. 35 s. ISBN 978-80-88688-78-5

ČIŽMÁROVÁ, K. 2008. Didaktika geografie I. Banská Bystrica: FPV UMB. 2008, 107 s. ISBN 978-80-8083-641-2

FRYKOVÁ, E. 2012. Environmentálna výchova v edukačnom procese. [online]. Bratislava: Metodicko-pedagogické centrum, 2012. [cit. 2018-09-22]. Dostupné na internete: <https://mpcedu.sk/sites/default/files/ucebne_zdroje/ RNDr.\%20Erika\%20Frykov\%C3\%A1/e._frykov_environment_lna_v_chova_ v_eduka_nom_procese\%5B1\%5D\%20Copy.pdf > ISBN 978-80-8052-441-8

HUBA, M. 2009. An insight into environmental geography in Slovakia. In Slovak Geography at the Beginning of the 21st Century: Geographia Slovaca 26. [online]. 2009, vol. 26 [cit. 2018-23-09]. Dostupné na internete: $<$ https://www.sav.sk/journals/uploads/12131149GS_26.pdf>. ISSN 1210-3519

JANKO, T. 2012. Neverbální prvky v učebnicích zeměpisu jako nástroj didaktické transformace. Brno: MU v Brne, 2012. 145 s. ISBN 978-80-201-6135-4.

JOHNSEN, E. B. 1993. Textbooks in the kaledoscope. A crtical survey of literature and research on educational texts. Oslo : Scandinavian University Press, 1993. 456 s. ISBN 8200215067

LEPIL, O. 2010. Teorie a praxe tvorby výukových materiáli̊. Olomouc: Univerzita Palackého v Olomouci, 2010. 97 s. ISBN 978-802-4424-897.

MADZIKOVÁ, A. 2001. K problematike miestneho regiónu (vybrané environmentálne aspekty). In III. národná konferencia: Environmentálna výchova a vzdelávanie v školách Slovenskej republiky. Košice: PF UPJŠ, 2001. ISBN 80-7097-439-7, s. 129-133.

MIKK, J. 2000. Textbook: Research and Writing (Baltische Studien Zur Erziehungs- Und Sozialwissenschaft. Frankfurt: Peter Lang GmbH, 2000. 426 p. ISBN 0820447595.

MLADÝ, K. 1988. Tvorba a výroba učebníc. Bratislava: SPN, 1988. 
NOVANSKÁ, V. 2014. Environmentálna výchova ako prierezová téma v edukačnom procese na slovenských základných školách. In Biológia ekológia chémia. [online]. 2014, vol. 18, no. 1 Dostupné na internete: $<$ http://bech.truni.sk/prilohy/BECH_1_2014.pdf> ISSN 1338-1024

O ŠKOLE. [cit. 2018-09-22] http://www.oskole.sk/

PRŮCHA, J. 1998. Učebnice: teorie a analýzy edukačního média: Přiručka pro studenty, učitele, autory učebnic a výzkumné pracovníky. Brno: Paido, 1998. 150 s. ISBN 80-85931-49-4.

PRŮCHA, J. 2002 Moderní pedagogika. Praha: Portál, 2002. 481 s. ISBN 807178631- 4.

SIKOROVÁ, Z. 2010. Učitel a učebnice : uživaní učebnic na 2. stupni základních škol. Ostrava : Ostravská univerzita, 2010. 127 s. ISBN 978-80-7368-923-0.

ŠTÁTNY VZDELÁVACÍ PROGRAM - GEOGRAFIA. Ministerstvo školstva, vedy, výskumu a športu Slovenskej republiky [cit. 2018-09-22] $<$ http://www.statpedu.sk/files/articles/dokumenty/statny-vzdelavaciprogram/geografia_isced2.pdf>

TUREK, I. 2008. Didaktika. Bratislava: Iura edition, 2008. ISBN 978-80-8078198-9.

TUREK, I. 2014. Didaktika. 3. vyd. Bratislava: Wolters Kluwer, 2014. ISBN 978-80-8168-004-5.

ZUJEV, D. 1986. Ako tvorit' učebnice. Bratislava: SNP, 1986.

ZBOROVŇA. [cit. 2018-09-22] https://www.zborovna.sk/naj.php

\section{DESIGN OF THE TEXTBOOK FOR ENVIRONMENTAL GEOGRAPHY}

\section{Summary}

Our design of the textbook is primary made for second grade students of Geography in primary schools in Slovakia. On the other hand, we can use the textbook also in the other lessons because of its cross-sectional character. Design of the textbook for Environmental Geography has a playful and motivational character. Students are forced to be interested in environmental issues on global, regional and local level. Content of the textbook is made to be comprehensible for second grade students in primary schools. There are some foreign words but we provide Slovak equivalent for every foreign word or a short explanation.

Content of our textbook deals with environmental issues divided into three main chapters and other sub-chapters. The textbook mentions not only environmental issues but also their locations and solutions. The widest field of environmental issues is covered in the chapter which deals with global level. At regional level students learn about environmental issues in Slovakia. Finally, at the local level students find information about village called Rabča. The village is located in the northwest of Slovakia. We consider the knowledge of our country to 
be very important for students. So that, more than a half of all information is written at regional and local level. Content of the textbook covers wider area of environmental themes as we can find in ISCED 2.

The textbook is not only study material but also motivational one. Students can find various interesting information about the world's environmental issues. They are also informed about various world days. For example, World Water Day which is celebrated every year on $22^{\text {nd }}$ of March. Students can also play games during their studying of environmental issues. We included two games in the text book, one called Ozone game and second one called Bingo. These games could be used as a motivational part of the lesson or as revision where students are already familiar with a topic. The textbook also includes various tasks which students have to complete. It means that textbook forces students to work in the lesson. Students are not only passive listeners of the teacher but also active members of the lesson. In this modern era, it is very difficult to catch students' attention. They can find many information on the Internet. So that we have decided to make textbook which includes various tasks which students can solve during the time they spend on the Internet. They can also find various links to web pages which show them interesting facts about particular environmental issues. Our textbook also provides link for interesting application for their smart phones. It is called Waste Atlas and it introduces various countries in the world and their waste management. Graphic design of the textbook is colourful and motivational for students. Our design has been made through Microsoft Word programme and its tools. We used various geometric shapes for important information in the text so that students' attention is caught at first sight. As students go through the text they meet with two pictograms which point out important facts or ask for help.

\section{Mgr. Michaela Strišková}

RNDr. Daša Oremusová, PhD.

Katedra geografie a regionálneho rozvoja FPV UKF v Nitre

Trieda A. Hlinku 1, 949 74, Nitra

E-mail: michaela.mlinarcikova@gmail.com,doremusova@ukf.sk 